\title{
Molecular epidemiology of hepatitis D virus circulating in Southwestern Nigeria
}

\author{
Oluyinka Oladele Opaleye ${ }^{1}$, Oluwatoyin Margaret Japhet ${ }^{2}$, Olubusuyi Moses Adewumi ${ }^{3}$, \\ Ewean Chukwuma Omoruyi ${ }^{4}$, Olusola Anuoluwapo Akanbi ${ }^{1}$, Adeolu Sunday Oluremi', Bo Wang ${ }^{5}$, \\ Hoang van Tong ${ }^{6}$, Thirumalaisamy P. Velavan ${ }^{6+}$ and C.-Thomas Bock ${ }^{5^{*+}}$
}

\begin{abstract}
Background: Hepatitis B virus (HBV) and hepatitis D virus (HDV) infections are major public health problems in sub-Saharan Africa. Whereas it is known that HBV infection is endemic in Nigeria, there is only little data about HDV prevalence available. Here, we assessed the HDV seroprevalence and determined the HDV and HBV genotypes distribution among HBsAg positive individuals in Southwestern Nigeria.

Methods: This cross-sectional study involved 188 serum samples from HBsAg positive outpatients recruited at four tertiary hospitals in Southwestern Nigeria. Anti-HDV antibodies were detected by ELISA while HDV-RNA was detected by RT-PCR. Sequencing followed by phylogenetic analyses and HBV genotype-specific PCR were used to characterize HDV and HBV genotypes, respectively.

Results: Out of $188 \mathrm{HBsAg}$ positive serum samples, 17 (9\%) showed detectable HDV-RNA. Anti-HDV antibodies test was possible from 103 samples and were observed in $4.9 \%$ (5/103) patients. There was no significant difference in HDV prevalence between four main cities across the country. $64.7 \%$ of HDV-RNA positive samples were from males and $35.3 \%$ from females $(P<0.05)$. No significant associations were observed with regard to HDV seroprevalence and available demographic factors. Phylogenetic analyses demonstrated a predominance of HDV genotype 1 and HBV genotype E among the HDV-RNA/HBsAg positive patients.

Conclusions: In conclusion, our study showed a high prevalence of HDV infection in HBsAg carriers and the predominance of HDV genotype 1 infection in Nigerian HBV endemic region. The findings contribute to a better understanding of the relevance of HDV/HBV co-infection and circulating genotypes.
\end{abstract}

Keywords: Hepatitis D virus, HDV genotype, Molecular epidemiology, HBV infection, Nigeria

\section{Background}

Hepatitis D virus (HDV) is a defective RNA virus presenting similarities to some plant viroids, which requires hepatitis $B$ virus (HBV) as a helper virus for its propagation. Among 240 million chronic HBV carriers reported worldwide [1], approx. 15 to 20 million individuals are also infected with HDV [2-4]. In Africa, of the estimated 65 million chronic HBV carriers, about one fourth of

\footnotetext{
*Correspondence: bockc@rki.de

Oluyinka Oladele Opaleye spent 3 months at the RKI to characterize the molecular epidemiology of the HBV and HDV isolates.

${ }^{\dagger}$ Equal contributors

${ }^{5}$ Department of Infectious Diseases, Division of Viral Gastroenteritis and Hepatitis Pathogens and Enteroviruses, Robert Koch Institute, Seestr. 10, D-13353 Berlin, Germany

Full list of author information is available at the end of the article
}

HBsAg-positive individuals show dual-infection with HDV [4]. Chronic HBV/HDV co-infection can lead more often to severe liver diseases, like fulminant hepatitis, if compared to HBV mono-infection [5], whereas HBV/ HDV super-infection is associated with chronic infection among $90 \%$ of the virus carriers [3].

HDV is a spherical hybrid particle of $\sim 36 \mathrm{~nm}$ in diameter, composed of an outer coat containing hepatitis B surface antigens (HBsAg) and host lipids. The inner nucleocapsid consists of small and large hepatitis $\mathrm{D}$ delta antigens (sHDAg and LHDAg) and a single-stranded, circular RNA molecule of $\sim 1.7 \mathrm{~kb}[6,7]$. The unique open reading frame of the HDV genome encodes the delta antigens. sHDAg is required for HDV genome synthesis while LHDAg inhibits HDV-RNA synthesis and is essential for HDV particle 
formation [8]. Currently, eight HDV genotypes (HDV1-8) have been described with variable geographical distribution [9-11]. HDV1 is the most common genotype that distributes globally [9]. HDV2 is prevalent in Asia while HDV3 is detectable in South America. In sub-Saharan countries, the prevalence of HDV1, HDV5, HDV6, HDV7 and HDV8 has been reported previously [4, 12, 13]. Clinically, HDV1 infection is associated with both severe and mild liver disease, whereas HDV2 and HDV3 are associated with mild clinical course and outbreaks of severe fulminant hepatitis, respectively [14]. However, there is limited information on the clinical course of the other five HDV genotypes.

The HDV prevalence has been reported in various parts of the world. In Africa, the anti-HDV antibody prevalence in $\mathrm{HBsAg}$ carriers was reported only in Cameroon (17.6\%) and Gabon (15.6\% to $70.6 \%)$ [13, 15, 16]. Recently, HDV prevalence in sub-Saharan Africa was estimated from $1.3 \%$ to $50 \%$ [4]. Although HBV is endemic in Nigeria, data on HDV seroprevalence are limited. A previous study showed that HDV antigen was detectable in $6.5 \%$ of patients with chronic hepatitis B in Southwest Nigeria [17]. In addition, another study reported an antiHDV prevalence of $12.5 \%$ in $96 \mathrm{HBsAg}$ positive patients [18]. Moreover, a recent study showed that HDV1 prevails with $53.3 \%$ in Southwestern Nigeria followed by the HDV5 (33.3 \%) and HDV6 (13.3 \%), which were more restricted to the northern part of Nigeria [4].

Early childhood transmission is considered to be the most important route of HBV infection in high endemic areas therefore HDV super-infections contribute considerably to the high burden of chronic liver disease [12]. Although the HBV vaccination program into the routine children immunization schedule has been introduced in 2004 [19], HBV infection still remains a major public health problem in Nigeria with $10-15 \%$ of the population positive for HBsAg [20]. Molecular epidemiology studies of HDV prevalence and determination of circulating $\mathrm{HBV}$ and $\mathrm{HDV}$ genotypes in $\mathrm{HBV}$ endemic regions of Africa are needed to assess and improve the control measures of $\mathrm{HBV} / \mathrm{HDV}$ co-infection. In this study, we therefore investigated the HDV seroprevalence and circulation of HBV and HDV genotypes in HBsAg positive serum samples from Southwestern Nigeria.

\section{Methods}

\section{Study area and serum sample collection}

One hundred and eighty-eight serum samples obtained from HBsAg positive outpatients were included in this cross-sectional study conducted between June and September 2014 in four tertiary hospitals in southwestern Nigeria. The four tertiary hospitals were Ladoke Akintola University Teaching Hospital in Osogbo, Ladoke Akintola University Teaching Hospital Ogbomoso, Obafemi
Awolowo Teaching hospital Ile-Ife, and University College Teaching Hospital Ibadan. Of the 188 samples, 123 were from Ibadan, 26 from Ogbomoso, 24 from Osogbo, and 15 from Ife. The outpatients came to the hospital for various complaints and routine examination. Therefore, no patient with severe liver disease was recruited. No information about treatment history was available from these outpatients. Due to small volume of the samples only 103 samples could be analysed for the presence of anti-HDV antibodies.

\section{Ethics}

Ethical approval was obtained from the Ladoke Akintola University Teaching hospital ethical committee. Informed written consent was sought and obtained from each of the participants in this study.

\section{Serology of HBV and HDV}

All samples had been tested and confirmed for HBsAg positivity using Rapid Kit (Micropoint Rapid Diagnostic, Micropoint Bioscience, Switzerland). Relative sensitivity and specificity were $>99 \%$ and $97.0 \%$ respectively, with accuracy of $98.5 \%$. HBsAg negative serum samples were excluded from the study. However, anti-HIV and anti$\mathrm{HCV}$ analyses have not been done in this study. Total anti-HDV antibodies (IgG and IgM) were detected using ELISA (ETI-AB-DELTAK-2, Dia-Sorin, Italy). All serological tests were performed following the manufacturer's instructions.

\section{Detection of HDV-RNA}

Nucleic acid was extracted from patient sera using High Pure Viral Nucleic Acid Kit (Roche, Grenzach-Wyhlen, Germany) following the manufacturer's instruction and stored until use in aliquots at $-80{ }^{\circ} \mathrm{C}$. We employed HDV-specific nested RT-PCR approach for HDV detection using primers designed for amplification of a highly conserved region of the HDV genome (LHDAg region, nucleotide 888 to 1122). The first round of RT-PCR was performed using a one-step RT-PCR kit (QIAgen, Hilden, Germany) and primer pair of HDV-04 and HDV-05 [21]. The primer pair HDV-06 and HDV-07 was used for nested PCR. Primer design and localization in the HDV genome has been previously described [21]. cDNA synthesis and pre-denaturation was performed at $50{ }^{\circ} \mathrm{C}$ for 30 min followed by $95{ }^{\circ} \mathrm{C}$ for $15 \mathrm{~min}$. PCR amplification was for 35 cycles including: denaturation at $94{ }^{\circ} \mathrm{C}$ for $30 \mathrm{~s}$, annealing at $56{ }^{\circ} \mathrm{C}$ for $30 \mathrm{~s}$, extending at $72{ }^{\circ} \mathrm{C}$ for $45 \mathrm{~s}$, followed by a final extension for $10 \mathrm{~min}$ at $72{ }^{\circ} \mathrm{C}$. The nested PCR was initiated by a denaturation step at $95{ }^{\circ} \mathrm{C}$ for $2 \mathrm{~min}$ and 29 cycles at $94{ }^{\circ} \mathrm{C}$ for $30 \mathrm{~s}, 58{ }^{\circ} \mathrm{C}$ for $30 \mathrm{~s}$, and $72{ }^{\circ} \mathrm{C}$ for $45 \mathrm{~s}$, followed by a final extension for $5 \mathrm{~min}$ at $72{ }^{\circ} \mathrm{C} .5 \mu \mathrm{l}$ of each PCR product was analysed by $1.5 \%$ agarose gel electrophoresis. A positive HDV PCR product 
was described by a band size of 235 bp (first PCR $323 \mathrm{bp}$ ) on the agarose gel. In order to avoid cross contamination, sample processing (DNA/RNA extraction, template preparation, and master mix preparation) and PCR was performed in separate laboratory rooms, which are all certified for molecular diagnostics using standard precautions.

\section{HDV genotyping and phylogenetic analysis}

HDV genotyping was performed by using direct sequencing. HDV positive PCR fragments were extracted from agarose gelelectrophoresis and purified using a gel extraction kit (Qiagen MinElute gel extraction kit, Hilden, Germany) according to the manufacturer's instruction. Sequencing reactions were performed using 1-5 $\mu \mathrm{l}$ purified PCR products, $1 \mu$ l BigDye reaction mix (Life Technologies, Applied Biosystems, Darmstadt, Germany) and $0.5 \mu \mathrm{M}$ of the primers HDV-06 and HDV-07. Sequencing results were analyzed using BioEdit 9.7 software (http://www.mbio.ncsu.edu/BioEdit/bioedit.html) and Geneious Pro (Version 5.5.7, Biomatters Ltd, Auckland,
New Zealand, http://www.geneious.com). The phylogenetic tree reconstruction and the mean value of genetic diversity of DNA sequences were carried out using MEGA 5 software [22]. The evolutionary history was inferred using the Neighbor-Joining method. The evolutionary distances were computed using the Maximum Composite Likelihood method. For alignment and HDV genotyping, eight prototype HDV-genotype sequences retrieved from the NCBI Gene bank were used (HDV-genotype 1: X77627, M92448, AB118848, AJ000558, X85253, AY633627, AF098261; HDV-genotype 2: AJ309880, X60193, U19598, AF104624; HDV-genotype 3: AB037948; HDV genotype 4: AF209859; HDV-genotype 5: AM183326; HDV genotype 6: AM183329; HDV-genotype 7: AM183333; HDV genotype 8: AX741169).

\section{HBV genotyping}

HBV-DNA was amplified by HBV genotype-specific nested PCR using generic outer primers (P1 and S1-2),

Table 1 Patient data, detection of HBsAg and anti-HDAg in Nigerian patient samples

\begin{tabular}{|c|c|c|c|c|c|c|c|}
\hline Patient & Age (years) & Gender (f/m) & Region/City & $\mathrm{HBsAg}(+/-)$ & anti-HDV $\lambda 450 \_620 \mathrm{~nm}$ & HDV-RNA (+/-) & HDV genotype \\
\hline $14-366$ & 45 & $f$ & Osogbo & + & n.d. & + & 1 \\
\hline $14-374$ & n.d. & n.d. & Ibadan & + & n.d. & + & 1 \\
\hline $14-375$ & n.d. & n.d. & Ibadan & + & n.d. & + & 1 \\
\hline $14-386$ & 30 & $\mathrm{~m}$ & Ibadan & + & 0.021 & - & \\
\hline $14-387$ & 34 & $f$ & Ibadan & + & n.d. & + & 1 \\
\hline $14-388$ & 38 & $\mathrm{~m}$ & Ibadan & + & n.d. & + & 1 \\
\hline 14-389 & n.d. & $\mathrm{m}$ & Ibadan & + & n.d. & + & 1 \\
\hline $14-392$ & 18 & $f$ & Ibadan & + & 0.884 & - & \\
\hline $14-403$ & 25 & $\mathrm{~m}$ & Ibadan & + & n.d. & + & 1 \\
\hline $14-406$ & 24 & $f$ & Ibadan & + & n.d. & + & 1 \\
\hline $14-408$ & 14 & $\mathrm{~m}$ & Ibadan & + & n.d. & + & 1 \\
\hline $14-415$ & 24 & $\mathrm{~m}$ & Ibadan & + & 1.016 & - & \\
\hline $14-420$ & 14 & $\mathrm{~m}$ & Ibadan & + & 0.803 & - & \\
\hline $14-425$ & 33 & $f$ & Ibadan & + & 0.701 & - & \\
\hline $14-426$ & 68 & $f$ & Ibadan & + & n.d. & + & 1 \\
\hline $14-432$ & n.d. & $\mathrm{m}$ & Ibadan & + & 1.044 & - & \\
\hline $14-444$ & n.d. & $f$ & Ibadan & + & n.d. & + & 1 \\
\hline $14-445$ & 34 & $\mathrm{~m}$ & Ife & + & n.d. & + & 1 \\
\hline $14-448$ & 30 & $\mathrm{~m}$ & Ife & + & n.d. & + & 1 \\
\hline $14-460$ & 46 & $f$ & Ibadan & + & 0.277 & - & \\
\hline $14-472$ & 19 & $\mathrm{~m}$ & Ibadan & + & n.d. & + & 1 \\
\hline $14-495$ & 49 & $\mathrm{~m}$ & Ibadan & + & n.d. & + & 1 \\
\hline $14-496$ & 34 & $\mathrm{~m}$ & Ibadan & + & n.d. & + & 1 \\
\hline $14-509$ & 32 & $\mathrm{~m}$ & Ibadan & + & 1.128 & - & \\
\hline $14-562$ & n.d. & n.d. & Osogbo & + & n.d. & + & 1 \\
\hline
\end{tabular}

Patient numbers are indicated as 14-XXX; the region/cities are located in south-western Nigeria within $200 \mathrm{~km}$; OD ( $\lambda$ 450_620 nm); OD of $>1.2$ is not reactive, OD of 0.9-1.2 is borderline reactive, $O D<0.9$ is reactive. n.d. is not defined or data not available 
followed by duplex primer mixtures containing typespecific inner primers as described elsewhere [23].

\section{Statistical analysis}

Statistical analysis was performed using SPSS version 15 (IBM Corporation, Armonk, NY, USA). Categorical data were compared by Fisher's exact test. Non-parametric data were compared by using the Chi-square test, with a 2-tailed $P$ value $<0.05$ considered to be statistically significant.

\section{Results}

\section{Sample characteristics and HDV prevalence}

Of the $188 \mathrm{HBsAg}$ positive serum samples from outpatients recruited at four tertiary hospitals in Southwestern Nigeria, 82 (43.6 \%) were from females and 106 (56.4 \%) were from males. The mean age of all the HBsAg positive patients was $32 \pm 10.8$ years, and there was no significant difference between males ( $32.2 \pm 11.4$ years) and females $(31.8 \pm 10.5$ years). Due to the low volume of serum samples available, only 103 of the $188 \mathrm{HBsAg}$ positive samples could be examined for prevalence of anti-HDV antibodies; however, HDV genome detection was possible from all 188 samples. Of 103 samples, five (4.9\%) were positive for anti-HDV antibodies (IgM and IgG). Unexpectedly, none of the anti-HDV antibodies positive samples were HDV-RNA positive. 17 of the 188 HBsAg-positive serum samples demonstrated detectable HDV-RNA given a HDV prevalence of $9 \%$ in our study population (Table 1, Fig. 1).

Determination of gender affinity showed that 11 of the 17 (64.7 \%) HDV-RNA positive serum samples were from males and six $(35.3 \%)$ were from females $(P=0.6)$. A more detailed analysis of the regional distribution in Southwestern Nigeria showed that HDV-RNA detection in HBsAg-positive individuals is more frequent in Ife $(2 / 15 ; 13.3 \%)$ than in any of the three remaining cities including Osogbo (2/24; $8.3 \%)$, Ibadan (12/123; $9.8 \%)$, and Ogbomoso (1/26; $3.8 \%)$. However, the difference was not statistically significant $(\mathrm{P}>0.05)$. Analysis of
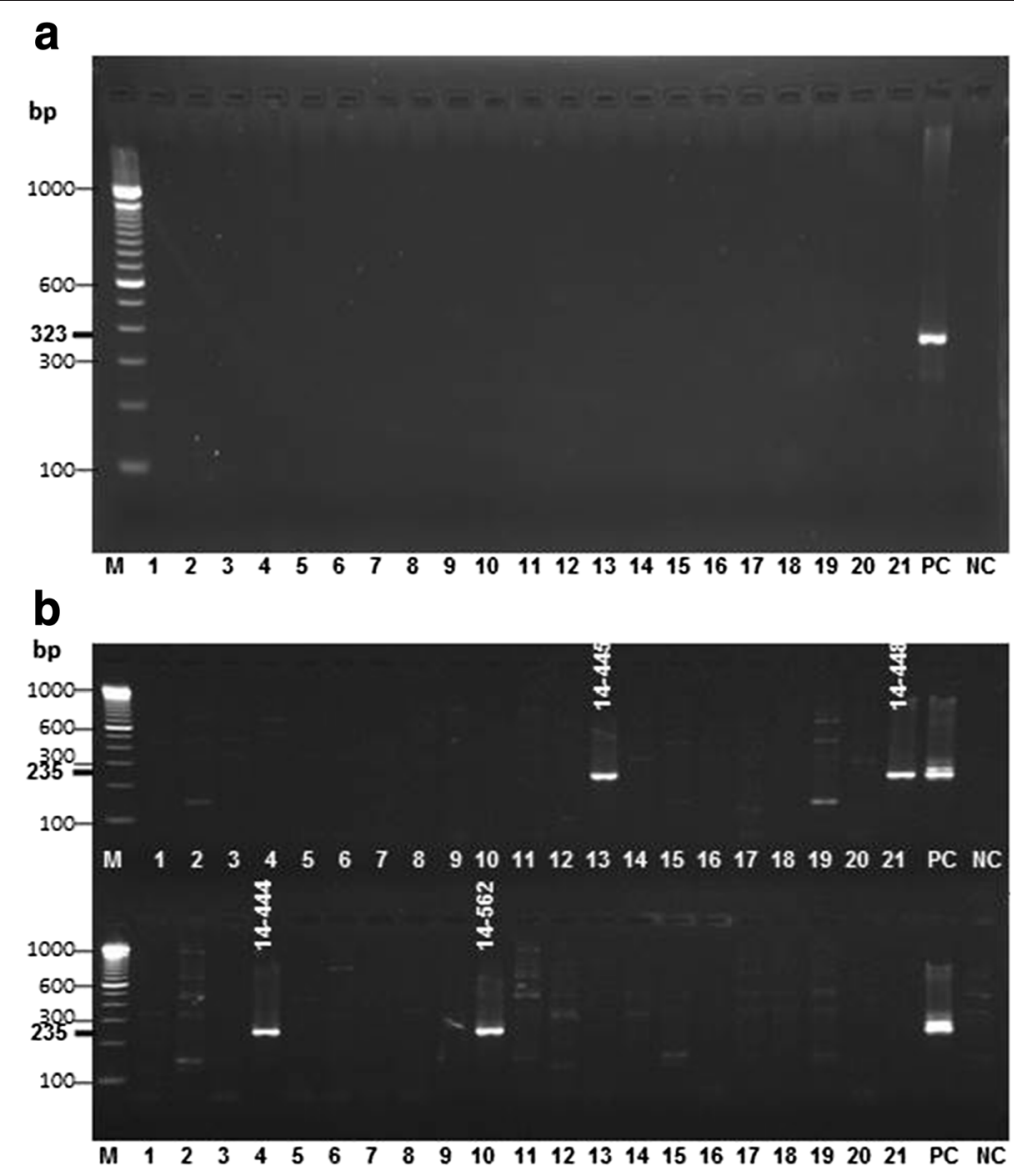

Fig. 1 Representative agarose gel electrophoreses of amplified HDV-products. a HDV specific nRT-PCRs showing results of the first PCR round (HDV-specific amplicon of $323 \mathrm{bp}$ ) and $\mathbf{b}$ nested PCR with an HDV-specific amplicon of $235 \mathrm{bp}$. Lanes 1-21 correspond to PCR results from serum samples. HDV-positive samples with correct size in (b) are denoted with the patient number, e.g., 14-445 (see (b) lane 13 and 21; upper lanes, and lane 4 and 10, lower lanes). PC is the HDV-positive control (acc. No. M21012, [27]); NC is the negative control. Lane M shows a 100 bp DNA ladder, base pairs (bp) of the marker are denoted at the left 


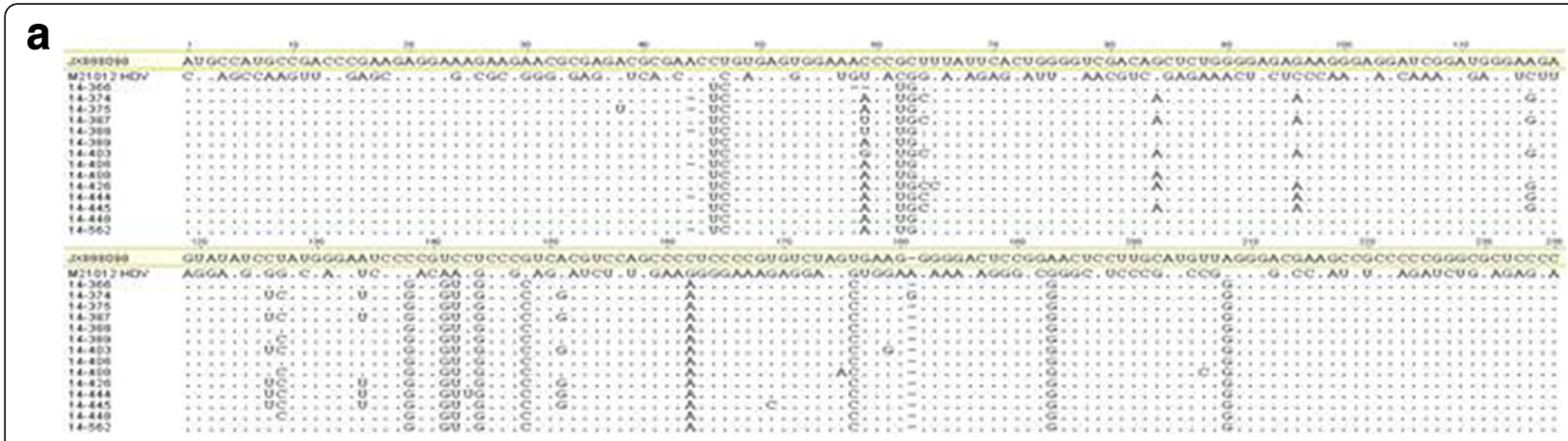

b

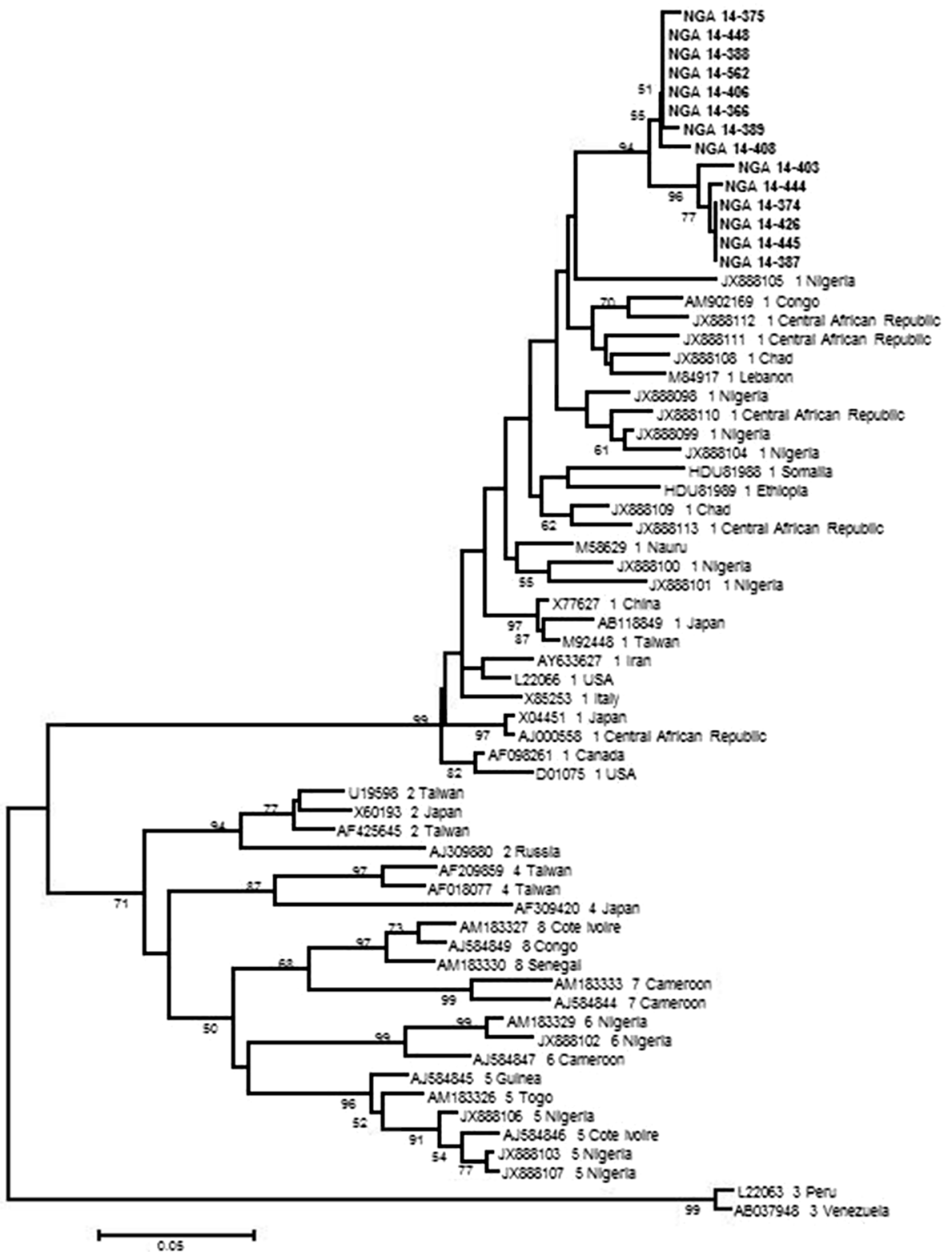

HDV 1

HDV 2

HDV 4

HDV 8

HDV 7

HDV 6

HDV 5

HDV 3

Fig. 2 (See legend on next page.) 


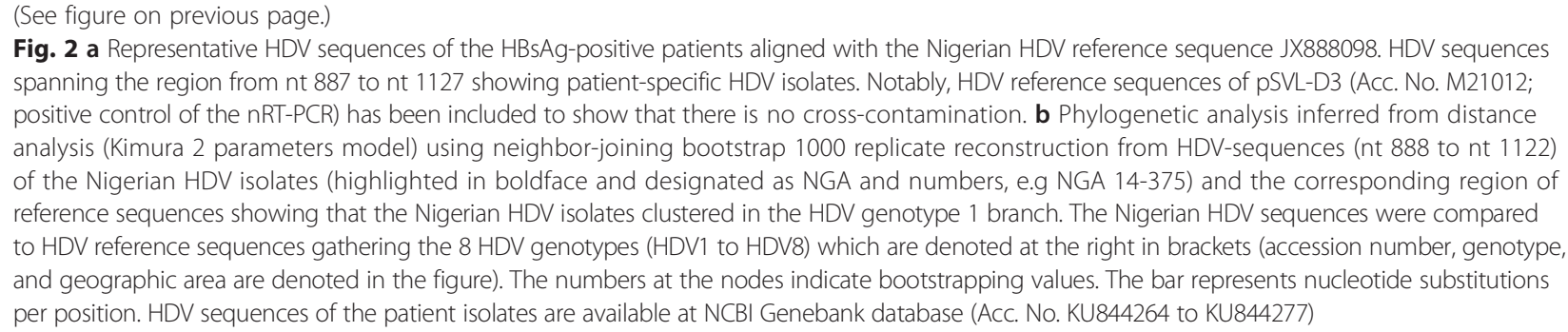

the age dependency of HDV-RNA detection showed that patients within the age range of $31-40$ years had highest prevalence of HDV-RNA with 7/17 (41.2\%), followed by the age group of 21-30 years with $3 / 17$ $(17.6 \%)$. The patients with age range of $11-20$ years, 41-50 years and $\geq 51$ years had similar prevalence of HDV-RNA with 2/17 (11.8\%). As expected, the lowest HDV-RNA prevalence was found within the age group of $0-10$ years with $1 / 17$ (5.9\%).

\section{HDV and HBV genotype distribution in the Nigerian study population}

In order to determine the circulation of HDV genotypes in Southwestern Nigeria, sequence data for nucleotide 888-1122 of HDV-RNA (LHDAg region) were obtained for 14 of the 17 HDV RNA-positive samples. The obtained HDV sequences were aligned using BioEdit, Geneious v. 8.1, and phylogenetic analysis was performed with prototype HDV sequences obtained from the NCBI GenBank database. The phylogenetic analysis of the 14 HDV isolates showed that all isolates clustered within the HDV genotype 1 clade (Fig. 2). HDV sequences are available at the NCBI GenBank database (Acc. No. KU844264 to KU844277). Additionally, in order to determine the HBV genotype in the HDV-RNA positive serum samples, HBV genotype-specific multiplex PCR was performed and the result showed that HBV genotype $\mathrm{E}$ prevails in all 17 HDV-RNA positive serum samples.

\section{Discussion}

Although HBV vaccination under the children immunization schedule has been available in Nigeria since 2004, HBV infection still remains a serious public health issue in this country with a prevalence of $10-15 \%$ in the population [20, 24]. Among the factors that shape the clinical course of HBV, co-infection with other viruses such as HCV, HIV and HDV is one major risk factor. In this study, we showed a high HDV infection prevalence of $9 \%$ in the Nigerian study population positive with HBsAg and the HDV1 was frequently circulating in Southwestern Nigeria.

Co-infection of hepatitis viruses is common because these viruses share the same route of transmission. HDV infection requires the presence of the HBV surface proteins (HBsAg) to assemble the infectious virus [6]. Therefore, HDV infection occurs regularly where HBV infection is endemic. Data concerning the prevalence of HDV infection in Nigeria as well as in other sub-Saharan African countries are limited. Nevertheless, a recent study showed that among HBsAg positive serum samples in endemic regions, approximately $10 \%$ were positive for anti-HDV antibodies and/or HDV-RNA ranging from $<2 \%$ detected in pregnant women in Burkina Faso to approx. $50 \%$ of liver disease patients in Central African Republic [4]. Our study on HBsAg positive individuals from four cities in Southwestern Nigeria showed that $9 \%$ were HDV-RNA positive and therefore representing active HDV infection. Only $4.9 \%$ of patients were anti-HDV antibody positive, which is significantly lower compared to another recent study showing $12.5 \%$ anti-HDV antibody positivity [18]. However, asymptomatic infected patients of this study showed an anti-HDV prevalence of $4.3 \%$ [18]. This value is in good agreement to our finding of $4.9 \%$ analysing only asymptomatic individuals. In addition, another previous study reported a HDV antigen prevalence of $6.5 \%$ in Nigerian HBsAg positive patients [17].

A limitation of our study is that we had not enough sample volume from each HBsAg-positive patient at disposal. Therefore, we could test only 103 of 188 serum samples for anti-HDAg antibodies. However, none of the anti-HDAg positive samples was HDV-RNA-positive and on the other hand none of the HDV-RNA positive samples tested positive for anti-HDAg (Table 1). Accordingly, we can only speculate about acute or chronic HDV infection of the patients. However, it can be hypothesized that the anti-HDAg positive patients without HDV-RNA detection were likely having chronic infection.

The results of our study revealed a high prevalence of HDV infection, which may contribute to significant morbidity and mortality in HBV-related liver diseases in Nigeria. In addition, although not statistically significant, analysis of gender affinity to HDV infection in our study indicated that male gender is predominantly affected with HDV $(64.7 \%)$ whereas female showed only $35.3 \%$ of the total HDV positive cohort. This is not unexpected and in concordance with a recent report showing that more than $75 \%$ of HDV infected patients were males [21]. 
At least eight HDV genotypes have been identified and HDV1 is the most common and is distributed throughout the world [25]. The predominance of HDV1 has been also described for sub-Sahara Africa [11, 25]. In this regard, our result showed that HDV1 was predominant in Southwestern Nigeria and no African-specific HDV5 to HDV8 were identified. However, HDV5 and HDV6 prevalence has been reported in the northern part of Nigeria [4]. Therefore, the samples from other parts in Nigeria are needed to characterize the predominance of circulating HDV genotypes in this country. Furthermore, HBV genotype $\mathrm{E}$ is the predominant $\mathrm{HBV}$ genotype detectable in Nigeria [26]. In agreement with this report, HBV genotype analyses of the HDV positive samples of our study cohort revealed that HBV genotype E predominates in Southwestern Nigeria. A close coevolution of HDV1 and HBV genotype E seems unlikely, since HDV1 prevails worldwide whereas HBV genotype $\mathrm{E}$ is largely confined to Africa and is thought to have a short evolutionary history [4].

\section{Conclusions}

In conclusion, our study provides important information in the HDV infection prevalence and molecular epidemiology of HBV and HDV genotypes circulating in endemic regions such as Southern Nigeria, which significantly contributes to improve the control measures of these hepatitis viruses. Future surveillance studies of HBV and HDV infections are therefore of public health importance not only for Nigeria but also for endemic regions in sub-Sahara Africa.

\section{Competing interests}

The authors declare that they have no competing interests.

\section{Authors' contributions}

OOO, TPV, and CTB designed the study. Input on the design was given by OMJ, OMA, ECO, OAA, and ASO. OOO and BW performed laboratory work. $\mathrm{OOO}, \mathrm{TPV}, \mathrm{CTB}, \mathrm{BW}$, and HVT analyzed and interpreted the data. Material and samples were provided by OMJ, OMA, ECO, OAA, and ASO. Manuscript was written by OOO, TPV, CTB and HVT with assistance and input from all contributing authors. All authors read and approved the final manuscript.

\section{Acknowledgement}

We appreciate Ute Obst, Claudia Zymelka, Marcel Schulze, and Roswitha Lorenz (all RKI, Berlin, Germany) for the excellent technical assistance and of Bolaji Egbewale for the statistical analysis.

\section{Funding}

We are particularly grateful to DAAD (German Academic Exchange Service) for funding the 3 month fellowship for O.O.O. to carry out the work at the RKI, Berlin, Germany. Bo Wang is supported by the China Scholarship Council (CSC), Beijing, China.

\section{Author details}

'Department of Medical Microbiology and Parasitology, Ladoke Akintola University of Technology, Ogbomoso, Nigeria. ${ }^{2}$ Department of Microbiology, Obafemi Awolowo University, lle Ife, Nigeria. ${ }^{3}$ Department of Virology, College of Medicine, University of Ibadan, Ibadan, Nigeria. ${ }^{4}$ Institute of Child Health, College of Medicine, University of Ibadan, Ibadan, Nigeria.

${ }^{5}$ Department of Infectious Diseases, Division of Viral Gastroenteritis and
Hepatitis Pathogens and Enteroviruses, Robert Koch Institute, Seestr. 10, D-13353 Berlin, Germany. ${ }^{6}$ Institute of Tropical Medicine, University of Tuebingen, Tuebingen, Germany.

Received: 14 January 2016 Accepted: 24 March 2016

Published online: 05 April 2016

\section{References}

1. World-Health-Organization. Hepatitis B, Fact sheet No 204, updated 2015. http://www.who.int/mediacentre/factsheets/fs204/en/. 2015.

2. Hadziyannis SJ. Review: hepatitis delta. J Gastroenterol Hepatol. 1997;12: 289-98.

3. World-Health-Organization. Hepatitis Delta Virus. Global Alert and Response (GAR). http://www.who.int/csr/disease/hepatitis/whocdscs. 2011.

4. Andernach IE, Leiss LV, Tarnagda ZS, Tahita MC, Otegbayo JA, Forbi JC, et al. Characterization of hepatitis delta virus in sub-Saharan Africa. J Clin Microbiol. 2014:52:1629-36.

5. Wedemeyer $\mathrm{H}$. Re-emerging interest in hepatitis delta: new insights into the dynamic interplay between HBV and HDV. J Hepatol. 2010;52:627-29.

6. Taylor JM. Hepatitis delta virus. Virology. 2006;344:71-6.

7. Taylor JM. Structure and replication of hepatitis delta virus RNA. Curr Top Microbiol Immunol. 2006:307:1-23.

8. Modahl LE, Lai MM. The large delta antigen of hepatitis delta virus potently inhibits genomic but not antigenomic RNA synthesis: a mechanism enabling initiation of viral replication. J Virol. 2000;74:7375-80.

9. Alvarado-Mora MV, Locarnini S, Rizzetto M, Pinho JR. An update on HDV: virology, pathogenesis and treatment. Antivir Ther. 2013;18:541-8.

10. Le Gal F, Gault E, Ripault MP, Serpaggi J, Trinchet JC, Gordien E, et al, Eighth major clade for hepatitis delta virus. Emerg Infect Dis. 2006;12: 1447-50.

11. Radjef N, Gordien E, Ivaniushina V, Gault E, Anais P, Drugan T, et al. Molecular phylogenetic analyses indicate a wide and ancient radiation of African hepatitis delta virus, suggesting a deltavirus genus of at least seven major clades. J Virol. 2004;78:2537-44.

12. Makuwa M, Caron M, Souquiere S, Malonga-Mouelet G, Mahe A, Kazanji M. Prevalence and genetic diversity of hepatitis $B$ and delta viruses in pregnant women in Gabon: molecular evidence that hepatitis delta virus clade 8 originates from and is endemic in central Africa. J Clin Microbiol. 2008:46:754-6.

13. Makuwa M, Mintsa-Ndong A, Souquiere S, Nkoghe D, Leroy EM, Kazanji M Prevalence and molecular diversity of hepatitis B virus and hepatitis delta virus in urban and rural populations in northern Gabon in central Africa. J Clin Microbiol. 2009;47:2265-8.

14. Hughes SA, Wedemeyer $\mathrm{H}$, Harrison PM. Hepatitis delta virus. Lancet. 2011:378:73-85.

15. Cakaloglu Y, Akyuz F, Bozaci M, Ibrisim D, Pinarbasi B, Demir K, et al. Prevalence and clinical significance of SEN-H virus in chronic hepatitis B, C and delta infections in Turkey. Turk J Gastroenterol. 2008;19:104-8.

16. Nakasone H, Sakugawa H, Shokita H, Nakayoshi T, Kawakami Y, Kinjo F, et al. Prevalence and clinical features of hepatitis delta virus infection in the Miyako Islands, Okinawa, Japan. J Gastroenterol. 1998;33:850-4.

17. Ojo OS, Akonai AK, Thursz M, Ndububa DA, Durosinmi MA, Adeodu OO, et al. Hepatitis D virus antigen in HBsAg positive chronic liver disease in Nigeria. East Afr Med J. 1998:75:329-31.

18. Nwokediuko SC, ljeoma U. Seroprevalence of antibody to HDV in Nigerians with hepatitis B virus-related liver diseases. Niger J Clin Pract. 2009;12:439-42.

19. Abdulraheem IS, Onajole AT, Jimoh AAG, Oladipo AR. Reasons for incomplete vaccination and factors for missed opportunities among rural Nigerian children. J Public Health Epidemiol. 2011;3:194-203.

20. Opaleye OO, Fagbami AH, Lalremruata A, Kun JF. Prevalence and association of human parvovirus B19V with hepatitis B and C viruses in Nigeria. J Med Virol. 2011:83:710-6

21. Sy BT, Ratsch BA, Toan NL, Song le H, Wollboldt C, Bryniok A, et al. High prevalence and significance of hepatitis $D$ virus infection among treatmentnaive HBsAg-positive patients in Northern Vietnam. PLoS One. 2013;8:e78094.

22. Tamura K, Peterson D, Peterson N, Stecher G, Nei M, Kumar S. MEGA5: molecular evolutionary genetics analysis using maximum likelihood, evolutionary distance, and maximum parsimony methods. Mol Biol Evol. 2011;28:2731-9 
23. Naito H, Hayashi S, Abe K. Rapid and specific genotyping system for hepatitis B virus corresponding to six major genotypes by PCR using type-specific primers. J Clin Microbiol. 2001;39:362-4.

24. Mabayoje VO, Akinwusi PO, Opaleye $\mathrm{OO}$, Aboderin OA, Egbewale BE, Fagbami AH. Prevalence of hepatitis $B$ surface antigen, hepatitis $C$ and human immunodeficiency virus antibodies in a population of students of tertiary institution in Nigeria. Afr J Cln Exper Microbiol. 2010;11:68-74.

25. Mansour W, Malick FZ, Sidiya A, Ishagh E, Chekaraou MA, Veillon P, et al. Prevalence, risk factors, and molecular epidemiology of hepatitis B and hepatitis delta virus in pregnant women and in patients in Mauritania. J Med Virol. 2012;84:1186-98.

26. Forbi JC, Vaughan G, Purdy MA, Campo DS, Xia GL, Ganova-Raeva LM, et al. Epidemic history and evolutionary dynamics of hepatitis $B$ virus infection in two remote communities in rural Nigeria. PLoS One. 2010;5:e11615.

27. Kuo MY, Chao M, Taylor J. Initiation of replication of the human hepatitis delta virus genome from cloned DNA: role of delta antigen. J Virol. 1989;63:1945-50.

Submit your next manuscript to BioMed Central and we will help you at every step:

- We accept pre-submission inquiries

- Our selector tool helps you to find the most relevant journal

- We provide round the clock customer support

- Convenient online submission

- Thorough peer review

- Inclusion in PubMed and all major indexing services

- Maximum visibility for your research

Submit your manuscript at www.biomedcentral.com/submit
Biomed Central 